\title{
Role of Non-Coding RNAs in Lung Circadian Clock Related Diseases
}

\author{
Srinivasan Chinnapaiyan ${ }^{1}$, Rajib Kumar Dutta ${ }^{1}\left(\mathbb{D}\right.$, Dinesh Devadoss ${ }^{1}$, Hitendra S Chand ${ }^{1}{ }^{(}$, \\ Irfan Rahman ${ }^{2}$ and Hoshang Jehangir Unwalla ${ }^{1, *}$ \\ 1 Department of Immunology and Nano-Medicine, Herbert Wertheim College of Medicine, Florida \\ International University, Miami, FL 33199, USA; schinnap@fiu.edu (S.C.); rdutt002@fiu.edu (R.K.D.); \\ ddevados@fiu.edu (D.D.); hchand@fiu.edi (H.S.C.) \\ 2 School of Medicine and Dentistry, University of Rochester Medical Center, Rochester, NY 14642, USA; \\ Irfan_Rahman@urmc.rochester.edu \\ * Correspondence: hunwalla@fiu.edu; Tel.: +1-305-348-3442; Fax: +1-305-243-6992
}

Received: 4 March 2020; Accepted: 21 April 2020; Published: 24 April 2020

\begin{abstract}
Circadian oscillations are regulated at both central and peripheral levels to maintain physiological homeostasis. The central circadian clock consists of a central pacemaker in the suprachiasmatic nucleus that is entrained by light dark cycles and this, in turn, synchronizes the peripheral clock inherent in other organs. Circadian dysregulation has been attributed to dysregulation of peripheral clock and also associated with several diseases. Components of the molecular clock are disrupted in lung diseases like chronic obstructive pulmonary disease (COPD), asthma and IPF. Airway epithelial cells play an important role in temporally organizing magnitude of immune response, DNA damage response and acute airway inflammation. Non-coding RNAs play an important role in regulation of molecular clock and in turn are also regulated by clock components. Dysregulation of these non-coding RNAs have been shown to impact the expression of core clock genes as well as clock output genes in many organs. However, no studies have currently looked at the potential impact of these non-coding RNAs on lung molecular clock. This review focuses on the ways how these non-coding RNAs regulate and in turn are regulated by the lung molecular clock and its potential impact on lung diseases.
\end{abstract}

Keywords: lung circadian clock; non-coding RNA; COPD; asthma; cigarette smoke

\section{Introduction}

The physiology and behavior of mammals are subject to daily oscillations driven by an endogenous circadian clock that consists of a central pacemaker in the brain's suprachiasmatic nucleus (SCN). The central pacemaker synchronizes subsidiary clocks in nearly every peripheral tissue tested [1]. Circadian rhythms (circa = about, dies = day) are near 24-h autonomous, self-sustained, biologic oscillations mediated by changes in the expression of clock genes [2]. Circadian rhythms are entrained to environmental cues, such as the day-night transition [2,3]. While the light-dark cycles are the predominant Zeitgebers (timing cues) for the central pacemaker, the peripheral pacemaker is often regulated and easily disrupted by metabolic status or environmental stimuli [4]. At the cellular level, circadian rhythmicity involves the molecular clock: a group of clock proteins that oscillate in a transcriptional-translational feedback loop. The central clock or central circadian pacemaker localized in the suprachiasmatic nucleus (SCN) of the hypothalamus in mammalian brain, was first reported by Mohawk et al., 2012 [2]. The central clock is entrained primarily by light followed by other physiological factors, such as feeding cues. Light enters the retina and signals via the retinal hypothalamic tract to the SCN. While most physiological processes were 'driven' by neural and hormonal output signals 
from the 'central' clock', the discovery of 'peripheral' clocks within every tissue and organ of the body has provided a focus towards understanding the link between circadian disruption and diseases [5].

Non-coding RNAs (ncRNAs) play an important role in gene regulation. The most prominent non-coding RNAs are microRNAs that are involved in post-transcriptional gene silencing. Other prominent ncRNAs involved in gene health and disease include long ncRNAs and small nucleolar RNAs (snoRNAs). Dysregulation of these RNAs can have a pronounced impact on disease progression. NcRNAs play distinct roles in clock physiology. They are involved in regulation of core clock genes and clock output genes. Likewise, ncRNAs in turn are also regulated by clock genes in several organs. Core clock genes such as Brain and Muscle ARNT-Like 1 (BMAL1), CLOCK, Period (PER), Cryptochrome (CRY) and SIRT1 have all been shown to be regulated by miRNAs in several tissues [6]. To date none of the studies have looked at the potential effects of an aberrant microRNAome on the regulation of clock genes. Our results have shown that TGF- $\beta 1$ a cytokine upregulated in smokers and COPD patients alters the bronchial epithelial microRNAome [7]. Some of these miRNAs are directly involved in regulating clock genes. It is well established that clock gene dysregulation in the lung promotes exacerbations in COPD as well as chronic inflammation [8-10]. This review discusses the reports of ncRNA mediated clock gene dysfunction observed in other tissues and its implications in lung diseases.

\section{Mechanism of Circadian Clock}

Both central and peripheral clocks use the same molecular machinery to 'time' the day. In each organ, interlocking repressing and activating transcriptional and translational feedback loops with a built-in 'delay' mechanism, culminate in the approximately 24-h rhythmic expression and activity of a set of core clock genes. In mammals, the molecular clock comprises at least ten genes that autoregulate each other in a transcriptional feedback loop [11]. The genes clock and BMAL1 (or Mop3) encode bHLH-PAS (basic helix-loop-helix; Per-ARNT-Single-mined) proteins that form positive limb of the feedback circuit [12]. CLOCK:BMAL1 heterodimers bind to the DNA promotor region of clock target genes at E-boxes (5'-CACGTG-3') to initiate transcription [13-15]. A set of genes transcribed by the CLOCK/BMAL1 are the PER (PER1 \& PER2) and CRY (CRY1 \& CRY2) genes. PER and CRY genes form the negative arm of the autoregulatory feedback loop $[13,16,17]$. Heterodimers of PER and CRY dimerize in the cytoplasm, followed by nuclear translocation where they inhibit CLOCK:BMAL1 transcriptional activity allowing the cycle to repeat [18-21].

The CLOCK protein with intrinsic histone acetyl transferase (HAT) activity associates with BMAL1 and binds to E-box elements to drive the expression of clock output genes, REV-ERB $\alpha / \beta$ and negative regulators PER and CRY genes, which in turn suppress the expression of BMAL1. CLOCK acetylates the $\mathrm{H} 3$ and $\mathrm{H} 4$ making the chromatin epigenetically favorable for transcription of downstream genes. CLOCK also acetylates BMAL1 and PER2 (recruited by Ac-BMAL1). Ac-PER2 recruits Sirtuin1 (SIRT1) which deacetylates histones, PER2 and BMAL1. This dissociates PER2 reverting to a repressive chromatin state. PER2 dissociation leads to dissociation of SIRT1 and the cycle is repeated [22]. The rhythmic deacetylation of histones at the circadian gene promoters by SIRT1 is sensitive to NAD ${ }^{+}$ levels [23,24]. Rutter et al. [25] have shown that the $\mathrm{NAD}^{+}: \mathrm{NADH}$ ratio plays an important role in binding of CLOCK:BMAL1 to DNA.

The PER/CRY heterodimer also serves as an activator complex and also drives the expression on the nuclear receptors REV-ERB $\alpha / \gamma$ and ROR $\alpha / \gamma$ (Retinoid-Related Orphan Receptor) [26]. These two receptors stabilize the oscillator by regulating the timing and amplitude of BMAL1 expression. Clock proteins are profoundly influenced by posttranslational modifications that affect both their activity and stability $[23,27]$. Outputs from the molecular clock are generated through transcription or repression of target genes. BMAL1 is regulated by rhythmic coordination with REV-ERB $\alpha$, a nuclear hormone receptor and clock output gene. REV-ERB $\alpha$ is a critical regulator of inflammation and metabolism. $\mathrm{REV}-\mathrm{ERB} \alpha$ function is modulated by small-molecule ligands and thus represents an exciting option for manipulation of the clock in disease states [28,29]. Although clock-controlled genes (CCGs) are called primary clock proteins, the molecular oscillator also dictates the timing of tissue and cell specific 
genes [30]. These tissue and cell specific clock gene regulated genetic programs are the hands of the clock, facilitating its temporal program on systems physiology. Therefore, disruption of clock gene expression inevitably disturbs the timing and amplitude of these CCGs and the physiological processes which they control and has been implicated in chronic diseases [31,32]. The lung function demonstrates a robust diurnal rhythm, with a daytime peak (12:00 h) and early morning minimum (04:00 h) in healthy individuals [4]. Moreover, the early morning decline in lung function concurred with increased risk of exacerbations among patients with COPD and asthma [1,4]. Furthermore, lung molecular clock plays a significant role in the pathophysiology of chronic lung disease [33].

\subsection{Circadian Molecular Clock in Lung Related Diseases}

Circadian regulation of respiratory function has been described in both, experimental animals [34,35] and healthy humans [36,37]. Sukumaran et al. [38] reported over 600 genes showing robust oscillations in gene expression with over two thirds of them expressed during the dark cycle, including genes of lung homeostasis and repair. Mice conditioned to chronic jet lag or shift work conditions led to disruption of clock gene expression in the lung. Moreover, expression of clock genes demonstrated sexual dimorphism with male and female mice resulting in different levels of clock and BMAL1 expression under these conditions [35].

Obstructive lung diseases like Asthma, COPD demonstrate time-of-day variations in respiratory symptoms, including nocturnal breathlessness, insomnia and an early morning decline in lung function exacerbated with increased cough and mucus hypersecretion [39-41]. The pathological hallmarks of obstructive lung diseases like mucus hypersecretion, bronchodilator responses, surfactant protein levels, steroid efficacy and chronic cough likewise demonstrate circadian patterns [8,29,35,37,42-45].

The club cells in the bronchial epithelium are primarily involved in maintaining the pulmonary immune response in the lung [29]. CXCL5, a neutrophilic chemokine is expressed by club-cells and its expression is clock-controlled and demonstrates time-of-day variations. Gibbs et al. [29] showed that this is due to binding of the glucocorticoid receptor (GR) to its binding sites on the CXCL5 promoter. Expression of GR is clock-controlled and binding of GR to CXCL5 suppresses its expression. These observations by Gibbs et. al. [29] possibly explain the increased frequency of exacerbations observed in COPD and Asthma. Ablation of BMAL1 leads to enhanced CXCL5 expression even in presence of normal levels of GR, resulting in exaggerated inflammatory responses to lipopolysaccharide and bacterial infection [29]. Deletion of BMAL1 or mimicking jet lag conditions in mice, led to increased susceptibility to viral replication, increased exacerbation of acute viral bronchiolitis, mucus hypersecretion and increased airway resistance [46]. Likewise, suppression of REV-ERB $\alpha$ has been associated with increase in pro-inflammatory cytokines and augmented inflammatory responses [47].

As discussed above, Sirtuin 1 (SIRT1), an NAD ${ }^{+}$-dependent deacetylase, affects the clock function by binding with CLOCK:BMAL1 complexes and subsequent deacetylation of BMAL1 and PER2 proteins $[23,24,48-50]$. SIRT1 activity is reduced in diseased states like COPD or upon exposure to cigarette smoke [51-53]. Acquired SIRT1 suppression upon exposure to cigarette smoke leads to increased acetylation of circadian clock proteins, culminating in abnormal clock gene expression and proinflammatory response in the lung [9]. Hence SIRT1 plays an important role in the lung molecular clock and its disruption has been linked to inflammation in lung diseases. Figure 1 shows a schematic representation of the effects of molecular clock dysregulation in lung diseases. 


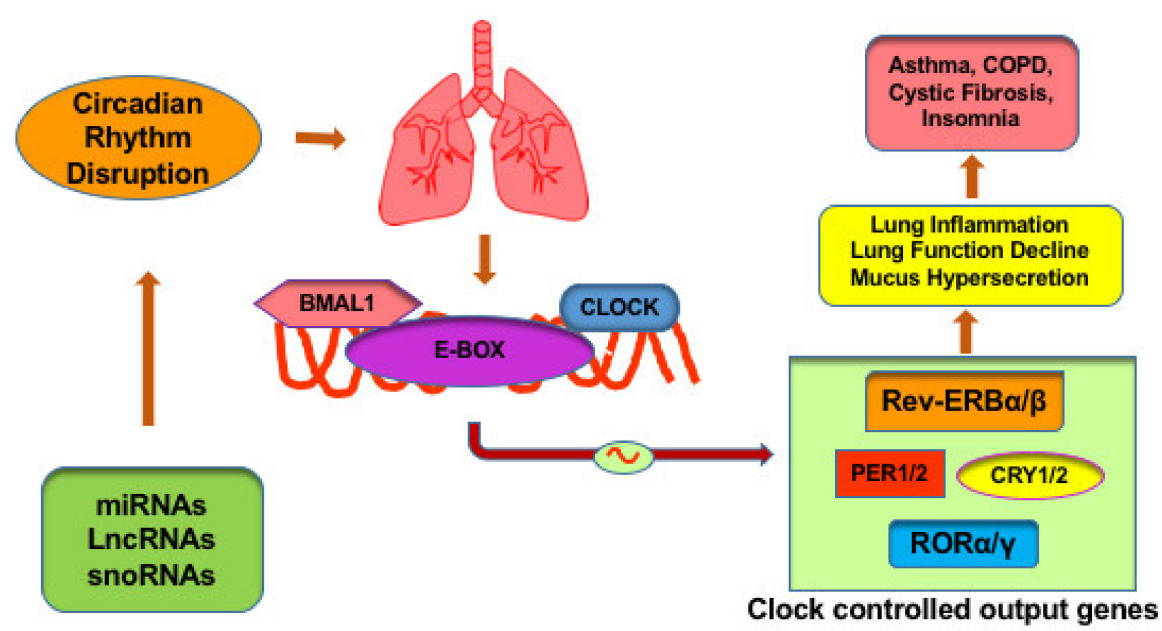

Figure 1. Schematic representation of ncRNAs regulation of lung molecular clock. Clock-controlled output genes are involved in lung function homeostasis. Outputs from the molecular clock are generated through transcription or repression of target genes. Clock genes plays a significant role in the lung pathophysiology of inflammation and metabolism. In the lung, disruption of these genes has been shown to promote exacerbations in chronic obstructive pulmonary disease (COPD), asthma, mucus hypersecretion, nocturnal breathlessness, insomnia as well as chronic inflammation.

\subsection{Role of Non-Coding RNAs in Molecular Clock Regulation: Implications to the Lung}

Non-coding RNAs can be considered important mediators of lung inflammation by virtue of their ability to regulate the expression of core clock genes as well as clock output genes thereby making them important mediators in inflammation and diseases. While microRNAs constitute the most studied non-coding RNAs and have been known to regulate clock gene expression by post-transcriptional gene silencing, there is increasing evidence for the role of other non-coding RNAs like long non-coding RNAs, and snoRNAs involved in maintaining or disrupting the molecular clock. Figure 2 shows the biogenesis of miRNAs and Long ncRNAs.

\subsection{Role of MicroRNAs in Molecular Clock Regulation: Implications for the Lung}

MicroRNAs (miRNAs) are a class of short (20-23-nucleotide), endogenous, single-stranded non-coding RNAs that play important roles in regulating the expression of target genes by directly binding to their mRNAs [54,55]. miRNA biogenesis is a sequential action of both nuclear and cytoplasmic processes. They are first transcribed as long primary miRNAs (pri-miRNAs), which are processed into precursor miRNAs (pre-miRNAs) by the enzyme drosha in the nucleus, followed by transport to the cytoplasm by RNA export factor Exportin 5 (XPO5) [56]. In the cytoplasm, the pre-miRNAs are further processed by DICER to $\sim 20-22$ bp mature miRNA duplexes with 2-nt $3^{\prime}$ overhangs [57-61]. The miRNA duplex is then incorporated into an Argonaute (Ago) proteins (AGO1, AGO2, AGO3 or AGO4) to form a miRNA-induced silencing complex (miRISC) [62,63] which subsequently mediates post-transcriptional gene silencing of the cognate RNA. miRNAs are also involved in transcriptional gene silencing whereby miRNAs are loaded to a specialized RNA-induced transcriptional silencing (RITS) complex, which consists of Ago1, and downregulates mRNA expression by chromatin remodeling [64]. 


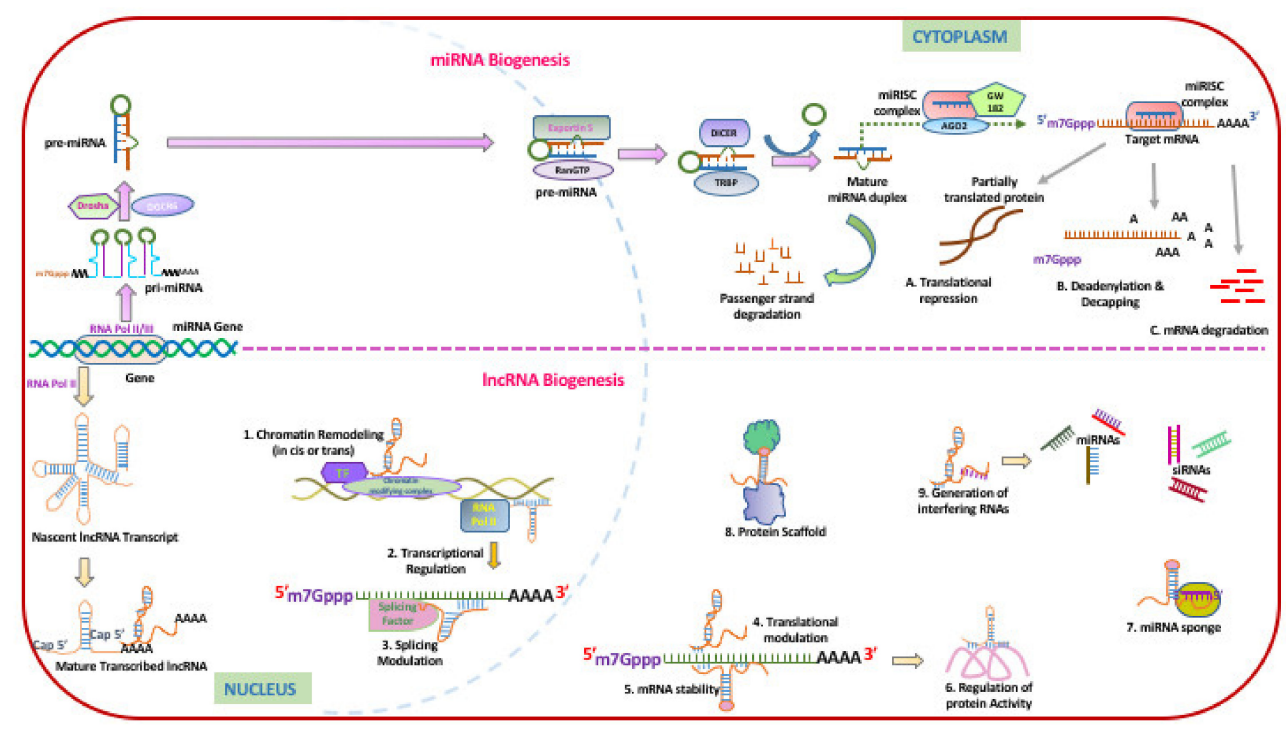

Figure 2. miRNAs and lncRNAs biogenesis and their role in epigenetic, transcriptional and posttranscriptional regulation. MiRNAs are short, single-stranded endogenous non-coding RNAs, of about 22 nucleotides that post-transcriptionally regulate gene expression. Most of the miRNA coding genes are found in introns and some are located as independent single transcriptional units or in clusters. miRNAs are involved in nearly all normal and developmental and pathological processes in humans. The miRNA biogenesis starts with transcription of gene into large primary transcript called pri-miRNA, which have $5^{\prime}$ caps and $3^{\prime}$ poly(A) tails2 and is typically mediated by RNA polymerase II and also some pre-miRNAs are generated by RNA polymerase III. Primary miRNA transcripts are processed into precursor miRNA (pre-miRNA) stem-loops of 60 nucleotides in length by the nuclear RNase III enzyme Drosha and its partner DGCR8. The transport of the pre-miRNA is mediated by the RanGTP-dependent nuclear transport receptor exportin-5 (EXP5). In cytoplasm, pre-miRNA are further cleaved by the endoribonuclease Dicer to mature $\sim 22$ nt long miRNA-miRNA *duplex. After the duplex is unwound, the guide strand, is then loaded with Argonaute (Ago2) proteins into the miRNA-induced silencing complex (miRISC), where it binds to target mRNA by partial complementarity with its $3^{\prime} \mathrm{UTR}$. This results in translational inhibition, mRNA degradation or deadenylation/decapping of the recognized mRNA target. IncRNAs are heterogenous regulatory elements comprise $>200$ nucleotides in length, and poorly conserved transcribed by RNA polymerase II, capped at the $5^{\prime}$ end, and polyadenylated at the $3^{\prime}$ end. IncRNAs can be classified as intergenic, intronic, exonic, antisense and overlapping based on their genomic location. lncRNAs have significant role in many biologic processes such as cellular development, differentiation and survival. Changes in lncRNAs expression has implicated in the development of disease. 1. IncRNAs act as guide by recruiting chromatin-modifying enzymes to target genes, either in cis or in trans to distant target genes. 2. IncRNAs modulate the gene expression either by interacting with transcriptional activator or interacting with transcriptional repressor thereby promoting and suppressing their transcription, respectively. 3. IncRNAs regulate the mRNA alternative splicing by associating with slicing factors. 4. IncRNAs influence the protein translation through interactions with binding of translation cofactors and regulators. 5. lncRNA:mRNA interaction provides mRNA stability. 6. IncRNAs influence post-translational protein modification, alter protein localization, regulate protein activity or act as components of protein complex. 7. IncRNAs can act as miRNA sponges, influence the expression levels of the endogenous miRNA targets. 8. IncRNAs serve as protein scaffolds, forming ribonucleoproteins and bringing proteins in proximity to organize nuclear architecture. 9. In addition, few lncRNAs act as miRNA or small interfering RNAs (siRNA) precursor.

miRNAs play an important role in regulating molecular clock. miRNAs can regulate clock genes or be regulated by clock genes, providing circadian regulation of their cognate targets. Shende et al. reported that microRNAs mir-142-3p and miR-494 directly target Bmal1 and regulates the circadian expression in the suprachiasmatic nuclei (SCN) [65,66]. The miR-142-5p and miR-142-3p miRNAs play 
an important role in negative feedback regulation of molecular clock, with miR-142-3p and miR-142-5p suppressing BMAL1 and SIRT1, respectively [67-69]. MiR-142 expression demonstrates circadian rhythmicity and is CLOCK-controlled, with CLOCK:BMAL1 binding to upstream E-box elements of miR-142 [55,69]. Hence miR-142 serves as a core clock-controlled miRNA.

miR-17-5p has been shown to directly regulate the CLOCK gene. The regulation is reciprocal in that CLOCK protein directly binds to the promoter region of miR-17 and activates expression of miR-17-5p which in turn binds to the $3^{\prime}$ UTR of CLOCK and suppresses its expression [70]. A number of microRNAs have been reported to target the PER genes of the molecular clock. Nagel et al. uncovered a microRNA cluster named miRNA-192/194 cluster that directly modulates the central components of the circadian clock [71,72]. Using a target-based screening method, they identified that endogenously expressed miR-192/194 cluster functions as a potential regulator and inhibitor of the entire Period gene family (PER1, PER2 and PER3). 3'-UTR of all PER genes contain putative target sites for miR-192/miR-194. The miR-34a-5p targets CRY1, PER1 and PER2) of molecular clockwork [59,73-75]. Likewise, miR-24 and miR-29b have been shown to directly suppress PER2 and PER3, respectively [59,76]. miR-29a and 30a are involved in regulating PER1 and PER2 [77]. Inhibition of PER genes has been shown to shorten the length of the circadian period and leads to an altered circadian cycle $[72,78,79]$. It is possible that this can lead to an increase in REV-ERB $\alpha$ levels leading to suppression of the tumor suppressor miR-122, since REV-ERB $\alpha$ is important in the post-transcriptional tuning of miR-122 [80,81]. Although the mature form of miR-122 expression does not oscillate, the expression of both pri-miR-122 and pre-miR-122 displays circadian oscillations [81]. miR-122 is an important tumor suppressor miRNA, as it inhibits tumor cell proliferation, induces apoptosis and suppresses metastasis in non-small cell lung cancer (NSCLSC) [60,61]. Shilts et. al. have shown that REV-ERB $\alpha$ expression is altered in lung cancer [82].

$\mathrm{Na}$ et al. [83] demonstrated that miR-181d and miR-191 exhibited inversely correlated circadian rhythm by controlling the circadian initiators, clock and Bmal1 in mouse liver [83]. In colorectal cancer, miR-181d plays an oncogenic role by directly targeting the $3^{\prime}$-UTRs of CRY2 and FBXL3 and by promoting glycolysis which implies the notion that dysregulated expression of clock gene leads the formation of tumor $[84,85]$. Cancer progression is also influenced by the circadian system whose functioning is based on the rhythmic expression of clock genes.

\subsection{TGF- $\beta$ in Altered microRNAome and Its Impact on Clock Regulation: Implications to the Lung}

TGF- $\beta 1$ expression is upregulated in the airways of smokers as well as COPD patients [86-89]. TGF- $\beta$ signaling has been shown to disrupt clock gene expression in many cell types. For instance, TGF- $\beta$ has been shown to suppress the expression of PER1, PER2 and REV-ERB $\alpha$ [90]. TGF- $\beta 1$ itself has been shown to upregulate BMAL1 in lung epithelial cells as well as fibroblasts [91]. TGF- $\beta$ itself is subject to circadian control by BMAL1 and CLOCK genes [91,92]. We have demonstrated that TGF- $\beta 1$ signaling upregulates multiple miRNAs capable of disrupting the lung molecular clock. We have observed that TGF- $\beta$ induces four miRNAs capable of targeting SIRT1, namely miR-449a [93,94] (2-fold or Log2 of 1.0), miR449b-5p [93] (7.07-fold or Log2 of 2.8), miR-126-3p [95] (2.5-fold or Log2 of 1.32) and miR-34a-5p [96,97] (3.7-fold or Log2 of 1.91). While only one of the miRNA, miR-449b made the cut off of Log2 of 2 (4-fold) in our manuscript [7], more than one miRNAs, upregulated at lower thresholds can have a profound impact on the specific target gene expression. Indeed, we have observed that TGF- $\beta 1$ suppresses SIRT1 expression in primary human bronchial epithelial cells (unpublished data). The aberrant microRNAome induced by TGF- $\beta 1$ in bronchial epithelial cells can directly impact core clock genes as well as clock output genes. We have demonstrated that TGF- $\beta 1$ treatment leads to a 1.78-fold (Log2 of 0.84) decrease in miR-140-5p known to target REV-ERB $\alpha$ [7]. It is possible that this can lead to an increase in REV-ERB $\alpha$ levels leading to suppression of the tumor suppressor miR-122.

Another clock controlling miRNA upregulated in our studies is miR-29b-3p (3.6-fold or Log 2 of 1.85) that targets PER1 [98]. TGF- $\beta 1$ upregulates miR-33b-5p (24.77-fold or Log2 of 4.63 [7]) known to suppress the clock output gene ROR $\alpha$ [99]. TGF- $\beta 1$ also suppresses another miRNA known to regulate 
ROR $\alpha$, namely miR-137 (7.6-fold or Log2 of 2.92 [7,100]). While suppression of miR-137 would be expected to increase the levels of $\operatorname{ROR} \alpha$, it is possible that the net result of these counteracting miRNAs is $R O R \alpha$ suppression given the increased magnitude of miR-33b-5p upregulation. We have already shown that cigarette smoke and HIV Tat induce TGF- $\beta 1$ signaling $[7,101,102]$. Hence it is possible that the bronchial epithelial microRNAome is disrupted in smokers and people living with HIV, leading to a dysfunctional lung molecular clock. This can manifest as chronic inflammation and increased exacerbations in obstructive lung diseases.

\subsection{Role of Non-Coding RNAs in Molecular Clock Regulation: Implication for the Lung}

Long non-coding RNAs (lncRNA) are mRNA like structures which lack protein coding potential. They can be located both in nucleus and cytoplasm, with a size of over 200 nucleotides. LncRNAs have been implicated in regulating various cellular functions by participating in chromatin modifications, mRNA decay, alternative splicing and transcription through cis and trans mechanisms [103] and are implicated in chronic lung diseases. In recent years, IncRNAs have also been shown to regulate various molecular pathways of the cellular circadian clock via an intriguing circadian-chromatin regulatory network. A pioneering study by Coon et al. [104] reported the association of lncRNAs with mammalian circadian rhythms while investigating the molecular regulation of melatonin hormone that helps to control the biologic rhythms of sleep-wake cycle. The RNA-Seq analysis of the rat pineal glands (an endocrine gland that produces and secretes melatonin), revealed 112 differentially expressed lncRNAs of which eight lncRNAs including lncSN001, IncSN004, lncSN012, lncSN016, lncSN056, lncSN081, lncSN134 and lncSN215 showed differential night/day expression.

Analysis of mammalian liver epigenome also revealed a significant association of a number of lncRNA species with circadian oscillations of metabolism regulating genes. Widespread changes in histone modifications but not DNA methylation showed strong association with transcriptional oscillations which included 1262 murine hepatic oscillating transcripts. These included 123 lncRNAs that were differentially expressed, as analyzed by deep RNA sequencing [105]. Among 123 lncRNAs, 19 lncRNAs showed robust transcriptional oscillations, indicating a synergistic role of lncRNAs with the histone modifications in regulating the circadian nature of gene expression.

Circadian oscillations regulate metabolism and physiology by multiple mechanisms. These diurnal rhythmic perceptions by the peripheral tissues such as retinal photoreceptor cells are critical in anticipating the required metabolic shifts. To understand the circadian process of the photoreceptor disc shedding and the retinal pigment epithelial (RPE) cell-mediated phagocytosis, RNA-Seq analysis of mouse retina was conducted [106]. Besides the core clock genes 191 differentially expressed lncRNAs were identified of which 16 showed strong association with the oscillating expression pattern. A detailed analysis of lncRNA ENMUST00000138486 revealed its location near the Mertk loci along with a $5-\mathrm{kb}$ promoter region, containing the promoter motifs for binding of CLOCK:BMAL1 and REV-ERB $\alpha[106]$.

As the circadian clock governs cell physiology and cell metabolism, any disruption in these diurnal rhythms results in accelerated aging and aging-associated comorbidities. Several lncRNA were shown to regulate aging and associated circadian rhythms [107]. The RNA-Seq of 4, 12 and 20 months old of zebrafish brain tissues analyzed at 2 diurnal points and the clustered analyses revealed differentially expressed 17,702 transcripts, where 6 lncRNAs showed noticeable diurnal oscillation at 12 months of age. Similar expression pattern was also noted with histone H3 lysine 9 tri-methylation (H3K9me3) that coincided with age- and diurnal-related changes. Subsequently, in another study using the zebrafish brain and the mice liver, a lncRNA Telomeric Repeat-containing RNA (TERRA) was found to be associated with circadian transcription factor BMAL1. Ablation of BMAL1 expression in a mouse model resulted in the disruption of TERRA's diurnal rhythmic expression and H3K9me3-mediated telomeric homeostasis, thus implicating, TERRA and BMAL-1 in aging-related telomeric erosion [108].

Similarly, the circadian clock disruption and the metabolic shift, both regulated by various IncRNAs, has also been associated with cancerous transformations. The impact of clock associated lncRNAs in 
hepatocellular carcinoma [109] showed that the lncRNA HULC upregulates the expression levels of CLOCK and its downstream targets, like PER1 and CRY1 in hepatoma cells in vivo. Bioinformatic analysis and the experimental validation performed in glioma, a lethal malignant brain tumor, showed that lncRNA UCA1 regulate CLOCK genes via miR-206 [110]. This UCA1/miR-206/CLOCK axis was implicated to show the integrative effect on proliferation and cell cycle of glioma cells.

Analysis of a metabolic disorder, non-alcoholic fatty liver disease (NAFLD showed that in addition to the significant amounts of mRNA transcripts, 291 lncRNA species were differentially expressed in the diseased conditions [111]. The GO and KEGG pathway analysis revealed 8 lncRNAs named fatty liver-related lncRNAs, FLRLs (FLRL1-8), to be associated with the circadian rhythm regulation. Further qPCR validation analysis confirmed that the lncRNAs FLRL1, FLRL2 and FLRL6 were involved in circadian clock by targeting the PER3, BMAL1 and PER2 genes, respectively.

Molecular clock and the lncRNAs has also been shown to regulate the cardiovascular physiology and endothelial system. The lncRNA NEAT1 inhibits the proliferation of human umbilical vein endothelial cells (HUVECs) when exposed to Trimethylamine N-oxide (TMAO), a chemical inducer of atherosclerotic development. TAMO induced the lncRNA NEAT1 which further regulates CLOCK:BMAL1 expression. Knocking down NEAT1 expression downregulates the CLOCK expression whereas the NEAT1 overexpression leads to upregulation of BMAL1 [112]. The regulatory role of lncRNA NEAT1 on CLOCK:BMAL1 gene expression was also confirmed using a NEAT1 targeted genetic editing approach in vascular smooth muscle cells. The cells were treated with acrolein, to induce cell death to model atherosclerotic plaque development, also considered as a circadian disorder [113].

\subsection{Role of Small Nucleolar RNAs (snoRNAs) in Molecular Clock Regulation: Implications to the Lung}

SnoRNAs are 60-300 nucleotide long non-coding RNAs primarily involved in the modification and processing of ribosomal RNA. These RNAs are primarily grouped into the C/D box snoRNAs which methylates the 2'-hydroxyl groups of the pre-rRNA precursor, and the H/ACA box snoRNAs which are involved in the modification of uridines to pseudouridines. snoRNAs act as scaffold to assemble protein complexes and guide the ribonucleoprotein complex to the target RNA mainly rRNA, using base-pairing between the snoRNA and its target [114-117]. Aitken and Semple showed that $18 \mathrm{~S}$ and $28 \mathrm{~S}$ pre-rRNA demonstrate circadian regulation that negatively corelates with expression of snoRNAs involved in modifying the rRNA precursor [118]. Another seminal study on the Prader-Willi syndrome (PWS), a genetic disorder of obesity, intellectual disability and sleep abnormalities [119], identified that PWS locus encompasses SNORD116 small nucleolar RNA (snoRNA) and a spliced IncRNA 116HG, which acts as a key regulator of diurnal energy expenditure of the brain. They followed fluorescent in-situ RNA/DNA hybridization (FISH) and chromatin isolation by RNA purification (ChiRP) approaches to show that the subnuclear lncRNA 116HG binds to RBBP5 (retinoblastoma binding protein 5) and stimulates histone methyl transferase activities. Deletion of SNORD116 in a mouse model lacking the IncRNA 116HG, exhibited increased energy expenditure due to dysregulation of the diurnally expressed mTor and the clock, CRY1 and PER2 circadian genes $[119,120]$. SNORA42 has been implicated in lung cancer [121] and many snoRNAs serve as biomarkers for lung cancer [122]. However, their effect on the lung molecular clock or their circadian regulation remains undiscovered.

\section{Conclusions}

Peripheral clocks play an important role in maintaining organ homeostasis; disruption of the peripheral clock can lead to disease states. While a number of studies have demonstrated the role of ncRNAs like miRNAs and long ncRNAs in regulating core clock genes as well as clock output genes in other organs, surprisingly none of the studies have explored a similar ncRNA-mediated disruption of the molecular clock in the lung. The aberrant microRNAome induced by TGF- $\beta$ signaling on the bronchial epithelium includes multiple microRNAs that can disrupt the lung molecular clock by suppressing or activating core clock genes as well as clock output genes. The effects of genes on inflammation and lung disease-like maladies has been extensively reviewed elsewhere [33]. This review 
provides a first peek at the possible pathophysiological mechanisms relating an aberrant microRNAome or dysregulated expression of long ncRNAs to lung circadian disruption with consequent inflammation and lung diseases.

Funding: This work was supported by 1R01HL147715-01 to Hoshang Unwalla.

Conflicts of Interest: The authors declare no conflict of interest.

\section{References}

1. Skloot, G.S. Nocturnal Asthma: Mechanisms and Management; The Mount Sinai journal of medicine: New York, NY, USA, 2002; Volume 69, pp. 140-147.

2. Mohawk, J.A.; Green, C.B.; Takahashi, J.S. Central and peripheral circadian clocks in mammals. Annu. Rev. Neurosci. 2012, 35, 445-462. [CrossRef]

3. Aschoff, J. Exogenous and Endogenous Components in Circadian Rhythms. Cold Spring Harb. Symp. Quant. Boil. 1960, 25, 11-28. [CrossRef] [PubMed]

4. Barnes, P.J. Circadian variation in airway function. Am. J. Med. 1985, 79, 5-9. [CrossRef]

5. Bechtold, D.A.; Gibbs, J.E.; Loudon, A.S. Circadian dysfunction in disease. Trends Pharmacol. Sci. 2010, 31, 191-198. [CrossRef] [PubMed]

6. Karbasforooshan, H.; Roohbakhsh, A.; Karimi, G. SIRT1 and microRNAs: The role in breast, lung and prostate cancers. Exp. Cell Res. 2018, 367, 1-6. [CrossRef]

7. Dutta, R.K.; Chinnapaiyan, S.; Rasmussen, L.; Raju, S.V.; Unwalla, H. A Neutralizing Aptamer to TGFBR2 and miR-145 Antagonism Rescue Cigarette Smoke- and TGF- $\beta$-Mediated CFTR Expression. Mol. Ther. 2019, 27, 442-455. [CrossRef]

8. Hoegh, S.V.; Sorensen, G.L.; Tornoe, I.; Lottenburger, T.; Ytting, H.; Nielsen, H.J.; Junker, P.; Holmskov, U. Long-term stability and circadian variation in circulating levels of surfactant protein D. Immunobiology 2010, 215, 314-320. [CrossRef]

9. Hwang, J.-W.; Sundar, I.K.; Yao, H.; Sellix, M.T.; Rahman, I. Circadian clock function is disrupted by environmental tobacco/cigarette smoke, leading to lung inflammation and injury via a SIRT1-BMAL1 pathway. FASEB J. 2013, 28, 176-194. [CrossRef]

10. Yao, H.; Sundar, I.K.; Huang, Y.; Gerloff, J.; Sellix, M.T.; Sime, P.J.; Rahman, I. Disruption of Sirtuin 1-Mediated Control of Circadian Molecular Clock and Inflammation in Chronic Obstructive Pulmonary Disease. Am. J. Respir. Cell Mol. Boil. 2015, 53, 782-792. [CrossRef]

11. Buhr, E.D.; Takahashi, J.S. Molecular components of the Mammalian circadian clock. Handb. Exp. Pharmacol. 2013, 217, 3-27. [CrossRef]

12. Lowrey, P.L.; Takahashi, J.S. Genetics of Circadian Rhythms in Mammalian Model Organisms. Adv. Genet. 2011, 74, 175-230. [CrossRef] [PubMed]

13. Gekakis, N. Role of the CLOCK Protein in the Mammalian Circadian Mechanism. Science 1998, 280, 1564-1569. [CrossRef] [PubMed]

14. Yoo, S.-H.; Ko, C.H.; Lowrey, P.L.; Buhr, E.D.; Song, E.-J.; Chang, S.; Yoo, O.J.; Yamazaki, S.; Lee, C.; Takahashi, J.S. A noncanonical E-box enhancer drives mouse Period2 circadian oscillations in vivo. Proc. Natl. Acad. Sci. USA 2005, 102, 2608-2613. [CrossRef]

15. Ohno, T.; Onishi, Y.; Ishida, N. A novel E4BP4 element drives circadian expression of mPeriod2. Nucleic Acids Res. 2006, 35, 648-655. [CrossRef] [PubMed]

16. HogenEsch, J.B.; Gu, Y.-Z.; Jain, S.; Bradfield, C.A. The basic-helix-loop-helix-PAS orphan MOP3 forms transcriptionally active complexes with circadian and hypoxia factors. Proc. Natl. Acad. Sci. USA 1998, 95, 5474-5479. [CrossRef] [PubMed]

17. Kume, K.; Zylka, M.J.; Sriram, S.; Shearman, L.P.; Weaver, D.; Jin, X.; Maywood, E.S.; Hastings, M.H.; Reppert, S.M. mCRY1 and mCRY2 are essential components of the negative limb of the circadian clock feedback loop. Cell 1999, 98, 193-205. [CrossRef]

18. Griffin, E.A.; Staknis, D.; Weitz, C.J. Light-Independent Role of CRY1 and CRY2 in the Mammalian Circadian Clock. Science 1999, 286, 768-771. [CrossRef]

19. Sangoram, A.M.; Sáez, L.; Young, M.W.; Weitz, C.J.; Takahashi, J.S.; Antoch, M.P.; Gekakis, N.; Staknis, D.; Whiteley, A.; Fruechte, E.M.; et al. Mammalian Circadian Autoregulatory Loop: A timeless ortholog and 
mPer1 interact and negatively regulate CLOCK-BMAL1-induced transcription. Neuron 1998, 21, 1101-1113. [CrossRef]

20. Field, M.D.; Maywood, E.S.; A O’Brien, J.; Weaver, D.; Reppert, S.M.; Hastings, M.H. Analysis of clock proteins in mouse SCN demonstrates phylogenetic divergence of the circadian clockwork and resetting mechanisms. Neuron 2000, 25, 437-447. [CrossRef]

21. Sato, T.K.; Yamada, R.G.; Ukai, H.; E Baggs, J.; Miraglia, L.J.; Kobayashi, T.J.; Welsh, D.K.; A Kay, S.; Ueda, H.R.; HogenEsch, J.B. Feedback repression is required for mammalian circadian clock function. Nat. Genet. 2006, 38, 312-319. [CrossRef]

22. Li, N.; Ren, A.; Wang, X.; Fan, X.; Zhao, Y.; Gao, G.F.; Cleary, P.; Wang, B. Influenza viral neuraminidase primes bacterial coinfection through TGF- $\beta$-mediated expression of host cell receptors. Proc. Natl. Acad. Sci. USA 2014, 112, 238-243. [CrossRef] [PubMed]

23. Nakahata, Y.; Kaluzova, M.; Grimaldi, B.; Sahar, S.; Hirayama, J.; Chen, D.; Guarente, L.P.; Sassone-Corsi, P. The NAD+-Dependent Deacetylase SIRT1 Modulates CLOCK-Mediated Chromatin Remodeling and Circadian Control. Cell 2008, 134, 329-340. [CrossRef] [PubMed]

24. Asher, G.; Gatfield, D.; Stratmann, M.; Reinke, H.; Dibner, C.; Kreppel, F.; Mostoslavsky, R.; Alt, F.W.; Schibler, U. SIRT1 Regulates Circadian Clock Gene Expression through PER2 Deacetylation. Cell 2008, 134, 317-328. [CrossRef] [PubMed]

25. Rutter, J.; Reick, M.; Wu, L.C.; McKnight, S.L. Regulation of Clock and NPAS2 DNA Binding by the Redox State of NAD Cofactors. Science 2001, 293, 510-514. [CrossRef]

26. Sundar, I.K.; Sellix, M.T.; Rahman, I. Redox regulation of circadian molecular clock in chronic airway diseases. Free Radic. Boil. Med. 2018, 119, 121-128. [CrossRef]

27. Hirayama, J.; Sahar, S.; Grimaldi, B.; Tamaru, T.; Takamatsu, K.; Nakahata, Y.; Sassone-Corsi, P. CLOCK-mediated acetylation of BMAL1 controls circadian function. Nature 2007, 450, 1086-1090. [CrossRef]

28. Trump, R.P.; Bresciani, S.; Cooper, A.W.J.; Tellam, J.P.; Wojno, J.; Blaikley, J.F.; Orband-Miller, L.A.; Kashatus, J.A.; Boudjelal, M.; Dawson, H.C.; et al. Optimized Chemical Probes for REV-ERB $\alpha$. J. Med. Chem. 2013, 56, 4729-4737. [CrossRef]

29. Gibbs, J.E.; Beesley, S.; Plumb, J.; Singh, D.; Farrow, S.; Ray, D.W.; Loudon, A. Circadian timing in the lung; a specific role for bronchiolar epithelial cells. Endocrinology 2008, 150, 268-276. [CrossRef]

30. Korenčič, A.; Kosir, R.; Bordyugov, G.; Lehmann, R.; Rozman, D.; Herzel, H. Timing of circadian genes in mammalian tissues. Sci. Rep. 2014, 4. [CrossRef] [PubMed]

31. Evans, J.A.; Davidson, A.J. Health Consequences of Circadian Disruption in Humans and Animal Models. Prog. Mol. Biol. Transl. Sci. 2013, 119, 283-323.

32. Marcheva, B.; Ramsey, K.M.; Peek, C.B.; Affinati, A.; Maury, E.; Bass, J. Circadian clocks and metabolism. Handb. Exp. Pharmacol. 2013, 217, 127-155. [CrossRef]

33. Sundar, I.K.; Yao, H.; Sellix, M.T.; Rahman, I. Circadian molecular clock in lung pathophysiology. Am. J. Physiol. Cell. Mol. Physiol. 2015, 309, L1056-L1075. [CrossRef] [PubMed]

34. Mortola, J.P.; Seifert, E.L. Circadian patterns of breathing. Respir. Physiol. Neurobiol. 2002, 131, 91-100. [CrossRef]

35. Hadden, H.; Soldin, S.J.; Massaro, D. Circadian disruption alters mouse lung clock gene expression and lung mechanics. J. Appl. Physiol. 2012, 113, 385-392. [CrossRef] [PubMed]

36. Boysen, P.G.; Block, A.J.; Wynne, J.W.; Hunt, L.A.; Flick, M.R. Nocturnal Pulmonary Hypertension in Patients with Chronic Obstructive Pulmonary Disease. Chest 1979, 76, 536-542. [CrossRef]

37. Spengler, C.; Shea, S. Endogenous Circadian Rhythm of Pulmonary Function in Healthy Humans. Am. J. Respir. Crit. Care Med. 2000, 162, 1038-1046. [CrossRef]

38. Sukumaran, S.; Jusko, W.J.; Dubois, D.C.; Almon, R.R. Light-dark oscillations in the lung transcriptome: Implications for lung homeostasis, repair, metabolism, disease, and drug action. J. Appl. Physiol. 2011, 110, 1732-1747. [CrossRef]

39. Petty, T.L. Circadian variations in chronic asthma and chronic obstructive pulmonary disease. Am. J. Med. 1988, 85, 21-23. [CrossRef]

40. Tsai, C.-L.; Brenner, B.E.; Camargo, C.A., Jr. Circadian-Rhythm Differences among Emergency Department Patients with Chronic Obstructive Pulmonary Disease Exacerbation. Chrono. Int. 2007, 24, 699-713. [CrossRef] 
41. Agusti, A.; Hedner, J.; Marín, J.M.; Barbé, F.; Cazzola, M.; Rennard, S.; Garcia-Navarro, A.A. Night-time symptoms: A forgotten dimension of COPD. Eur. Respir. Rev. 2011, 20, 183-194. [CrossRef]

42. Yao, H.; Rahman, I. Current concepts on oxidative/carbonyl stress, inflammation and epigenetics in pathogenesis of chronic obstructive pulmonary disease. Toxicol. Appl. Pharmacol. 2011, 254, 72-85. [CrossRef] [PubMed]

43. Thomas, A.; Petro, W.; Konietzko, N. The circadian rhythm of ciliary beat frequency of human nasal cilia in probands with healthy lungs and in patients with chronic obstructive lung disease. Includes adrenergic stimulation by terbutaline. Pneumologie 1993, 47, 526-530.

44. Gebel, S.; Gerstmayer, B.; Kuhl, P.; Borlak, J.; Meurrens, K.; Müller, T. The Kinetics of Transcriptomic Changes Induced by Cigarette Smoke in Rat Lungs Reveals a Specific Program of Defense, Inflammation, and Circadian Clock Gene Expression. Toxicol. Sci. 2006, 93, 422-431. [CrossRef]

45. Casale, R.; Pasqualetti, P. Cosinor Analysis of Circadian Peak Expiratory Flow Variability in Normal Subjects, Passive Smokers, Heavy Smokers, Patients with Chronic Obstructive Pulmonary Disease and Patients with Interstitial Lung Disease. Respiration 1997, 64, 251-256. [CrossRef] [PubMed]

46. Ehlers, A.; Xie, W.; Agapov, E.; Brown, S.; Steinberg, D.; Tidwell, R.; Sajol, G.; Schutz, R.; Weaver, R.; Yu, H.; et al. BMAL1 links the circadian clock to viral airway pathology and asthma phenotypes. Mucosal Immunol. 2017, 11, 97-111. [CrossRef] [PubMed]

47. Lechasseur, A.; Jubinville, É.; Routhier, J.; Bérubé, J.; Hamel-Auger, M.; Talbot, M.; Lamothe, J.; Aubin, S.; Paré, M.; Beaulieu, M.; et al. Exposure to electronic cigarette vapors affects pulmonary and systemic expression of circadian molecular clock genes. Physiol. Rep. 2017, 5, e13440. [CrossRef] [PubMed]

48. Belden, W.J.; Dunlap, J.C. SIRT1 Is a Circadian Deacetylase for Core Clock Components. Cell 2008, 134, 212-214. [CrossRef] [PubMed]

49. Imai, S.-I.; Armstrong, C.M.; Kaeberlein, M.; Guarente, L. Transcriptional silencing and longevity protein Sir2 is an NAD-dependent histone deacetylase. Nature 2000, 403, 795-800. [CrossRef]

50. Grimaldi, B.; Nakahata, Y.; Kaluzova, M.; Masubuchi, S.; Sassone-Corsi, P. Chromatin remodeling, metabolism and circadian clocks: The interplay of CLOCK and SIRT1. Int. J. Biochem. Cell Boil. 2009, 41, 81-86. [CrossRef]

51. Rajendrasozhan, S.; Yang, S.-R.; Kinnula, V.L.; Rahman, I. SIRT1, an Antiinflammatory and Antiaging Protein, Is Decreased in Lungs of Patients with Chronic Obstructive Pulmonary Disease. Am. J. Respir. Crit. Care Med. 2008, 177, 861-870. [CrossRef]

52. Yao, H.; Chung, S.; Hwang, J.-W.; Rajendrasozhan, S.; Sundar, I.K.; Dean, D.A.; McBurney, M.W.; Guarente, L.; Gu, W.; Rönty, M.; et al. SIRT1 protects against emphysema via FOXO3-mediated reduction of premature senescence in mice. J. Clin. Investig. 2012, 122, 2032-2045. [CrossRef]

53. Yang, S.-R.; Wright, J.; Bauter, M.; Seweryniak, K.; Kode, A.; Rahman, I. Sirtuin regulates cigarette smoke-induced proinflammatory mediator release via RelA/p65 NF-kB in macrophages in vitro and in rat lungs in vivo: Implications for chronic inflammation and aging. Am. J. Physiol. Cell. Mol. Physiol. 2007, 292, L567-L576. [CrossRef]

54. Bartel, D.P. MicroRNAs. Cell 2004, 116, 281-297. [CrossRef]

55. Dutta, R.K.; Chinnapaiyan, S.; Unwalla, H. Aberrant MicroRNAomics in Pulmonary Complications: Implications in Lung Health and Diseases. Mol. Ther. Nucleic Acids 2019, 18, 413-431. [CrossRef] [PubMed]

56. Lin, S.; Gregory, R.I. MicroRNA biogenesis pathways in cancer. Nat. Rev. Cancer 2015, 15, 321-333. [CrossRef] [PubMed]

57. Treiber, T.; Treiber, N.; Meister, G. Regulation of microRNA biogenesis and its crosstalk with other cellular pathways. Nat. Rev. Mol. Cell Boil. 2018, 20, 5-20. [CrossRef] [PubMed]

58. Haase, A.D.; Jaskiewicz, L.; Zhang, H.; Lainé, S.; Sack, R.; Gatignol, A.; Filipowicz, W. TRBP, a regulator of cellular PKR and HIV-1 virus expression, interacts with Dicer and functions in RNA silencing. EMBO Rep. 2005, 6, 961-967. [CrossRef]

59. O’Brien, J.; Hayder, H.; Zayed, Y.; Peng, C. Overview of MicroRNA Biogenesis, Mechanisms of Actions, and Circulation. Front. Endocrinol. 2018, 9, 402. [CrossRef]

60. Wahid, F.; Shehzad, A.; Khan, T.; Kim, Y.Y. MicroRNAs: Synthesis, mechanism, function, and recent clinical trials. Biochim. et Biophys. Acta BBA Bioenerg. 2010, 1803, 1231-1243. [CrossRef]

61. Macfarlane, L.-A.; Murphy, P.R. MicroRNA: Biogenesis, Function and Role in Cancer. Curr. Genom. 2010, 11, 537-561. [CrossRef] 
62. Kim, V.N.; Han, J.; Siomi, M.C. Biogenesis of small RNAs in animals. Nat. Rev. Mol. Cell Boil. 2009, 10, 126-139. [CrossRef] [PubMed]

63. Kawamata, T.; Tomari, Y. Making RISC. Trends Biochem. Sci. 2010, 35, 368-376. [CrossRef] [PubMed]

64. Khraiwesh, B.; Arif, M.A.; Seumel, G.I.; Ossowski, S.; Weigel, D.; Reski, R.; Frank, W. Transcriptional Control of Gene Expression by MicroRNAs. Cell 2010, 140, 111-122. [CrossRef] [PubMed]

65. Shende, V.R.; Neuendorff, N.; Earnest, D.J. Role of miR-142-3p in the Post-Transcriptional Regulation of the Clock Gene Bmal1 in the Mouse SCN. PLoS ONE 2013, 8, e65300. [CrossRef] [PubMed]

66. Shende, V.R.; Goldrick, M.M.; Ramani, S.; Earnest, D.J. Expression and Rhythmic Modulation of Circulating MicroRNAs Targeting the Clock Gene Bmal1 in Mice. PLoS ONE 2011, 6, e22586. [CrossRef] [PubMed]

67. Olena, A.F.; Patton, J.G. Genomic organization of microRNAs. J. Cell. Physiol. 2010, 222, 540-545. [CrossRef]

68. Kim, Y.K.; Kim, V.N. Processing of intronic microRNAs. EMBO J. 2007, 26, 775-783. [CrossRef]

69. Lin, S.-L.; Miller, J.D.; Ying, S.-Y. Intronic MicroRNA (miRNA). J. Biomed. Biotechnol. 2006, 2006, 1-13. [CrossRef]

70. Ramalingam, P.; Palanichamy, J.K.; Singh, A.; Das, P.; Bhagat, M.; Kassab, M.A.; Sinha, S.; Chattopadhyay, P. Biogenesis of intronic miRNAs located in clusters by independent transcription and alternative splicing. RNA 2013, 20, 76-87. [CrossRef]

71. Nagel, R.; Clijsters, L.; Agami, R. The miRNA-192/194 cluster regulates the Period gene family and the circadian clock. FEBS J. 2009, 276, 5447-5455. [CrossRef] [PubMed]

72. Lee, Y.; Kim, M.; Han, J.; Yeom, K.-H.; Lee, S.; Baek, S.H.; Kim, V.N. MicroRNA genes are transcribed by RNA polymerase II. EMBO J. 2004, 23, 4051-4060. [CrossRef] [PubMed]

73. Cai, X.; Hagedorn, C.H.; Cullen, B.R. Human microRNAs are processed from capped, polyadenylated transcripts that can also function as mRNAs. RNA 2004, 10, 1957-1966. [CrossRef] [PubMed]

74. Mazzoccoli, G.; Colangelo, T.; Panza, A.; Rubino, R.; Tiberio, C.; Palumbo, O.; Carella, M.; Trombetta, D.; Gentile, A.; Tavano, F.; et al. Analysis of clock gene-miRNA correlation networks reveals candidate drivers in colorectal cancer. Oncotarget 2016, 7, 45444-45461. [CrossRef] [PubMed]

75. Hasakova, K.; Reis, R.; Vician, M.; Zeman, M.; Herichova, I. Expression of miR-34a-5p is up-regulated in human colorectal cancer and correlates with survival and clock gene PER2 expression. PLoS ONE 2019, 14, e0224396. [CrossRef] [PubMed]

76. Borchert, G.M.; Lanier, W.; Davidson, B.L. RNA polymerase III transcribes human microRNAs. Nat. Struct. Mol. Boil. 2006, 13, 1097-1101. [CrossRef] [PubMed]

77. Chen, R.; D'Alessandro, M.; Lee, C. miRNAs are required for generating a time delay critical for the circadian oscillator. Curr. Boil. 2013, 23, 1959-1968. [CrossRef]

78. Takahashi, J.S.; Hong, H.-K.; Ko, C.H.; McDearmon, E.L. The genetics of mammalian circadian order and disorder: Implications for physiology and disease. Nat. Rev. Genet. 2008, 9, 764-775. [CrossRef]

79. Ju, J.; Wu, S.; Fesler, A. Implications of Circadian Rhythm Regulation by microRNAs in Colorectal Cancer. Cancer Transl. Med. 2016, 2, 1-6. [CrossRef]

80. Esau, C.; Davis, S.; Murray, S.F.; Yu, X.X.; Pandey, S.K.; Pear, M.; Watts, L.; Booten, S.L.; Graham, M.; McKay, R.; et al. miR-122 regulation of lipid metabolism revealed by in vivo antisense targeting. Cell Metab. 2006, 3, 87-98. [CrossRef]

81. Gatfield, D.; Le Martelot, G.; Vejnar, C.E.; Gerlach, D.; Schaad, O.; Fleury-Olela, F.; Ruskeepää, A.-L.; Orešič, M.; Esau, C.C.; Zdobnov, E.M.; et al. Integration of microRNA miR-122 in hepatic circadian gene expression. Genome Res. 2009, 23, 1313-1326. [CrossRef]

82. Shilts, J.; Chen, G.; Hughey, J.J. Evidence for widespread dysregulation of circadian clock progression in human cancer. Peer] 2018, 6, e4327. [CrossRef] [PubMed]

83. Na, Y.-J.; Sung, J.H.; Lee, S.C.; Lee, Y.-J.; Choi, Y.J.; Park, W.-Y.; Shin, H.S.; Kim, J.H. Comprehensive analysis of microRNA-mRNA co-expression in circadian rhythm. Exp. Mol. Med. 2009, 41, 638-647. [CrossRef]

84. Guo, X.; Zhu, Y.; Hong, X.; Zhang, M.; Qiu, X.; Wang, Z.; Qi, Z.; Hong, X. miR-181d and c-myc-mediated inhibition of CRY2 and FBXL3 reprograms metabolism in colorectal cancer. Cell Death Dis. 2017, 8, e2958. [CrossRef]

85. Wood, P.A.; Yang, X.; Hrushesky, W. Clock Genes and Cancer. Integr. Cancer Ther. 2009, 8, 303-308. [CrossRef] [PubMed]

86. Aubert, J.-D.; Dalal, B.I.; Bai, T.R.; Roberts, C.R.; Hayashi, S.; Hogg, J.C. Transforming growth factor beta 1 gene expression in human airways. Thorax 1994, 49, 225-232. [CrossRef] 
87. Vignola, A.M.; Chanez, P.; Chiappara, G.; Merendino, A.; Zinnanti, E.; Bousquet, J.; Bellia, V.; Bonsignore, G. Release of transforming growth factor-beta (TGF- $\beta$ ) and fibronectin by alveolar macrophages in airway diseases. Clin. Exp. Immunol. 1996, 106, 114-119. [CrossRef]

88. Vignola, A.M.; Chanez, P.; Chiappara, G.; Merendino, A.; Pace, E.; Rizzo, A.; La Rocca, A.M.; Bellia, V.; Bonsignore, G.; Bousquet, J. Transforming Growth Factor- $\beta$ Expression in Mucosal Biopsies in Asthma and Chronic Bronchitis. Am. J. Respir. Crit. Care Med. 1997, 156, 591-599. [CrossRef]

89. Takizawa, H.; Tanaka, M.; Takami, K.; Ohtoshi, T.; Ito, K.; Satoh, M.; Okada, Y.; Yamasawa, F.; Nakahara, K.; Umeda, A. Increased Expression of Transforming Growth Factor- $\beta 1$ in Small Airway Epithelium from Tobacco Smokers and Patients with Chronic Obstructive Pulmonary Disease (COPD). Am. J. Respir. Crit. Care Med. 2001, 163, 1476-1483. [CrossRef] [PubMed]

90. Gast, H.; Gordic, S.; Petrzilka, S.; Lopez, M.; Müller, A.; Gietl, A.; Hock, C.; Birchler, T.; Fontana, A. Transforming growth factor-beta inhibits the expression of clock genes. Ann. New York Acad. Sci. 2012, 1261, 79-87. [CrossRef] [PubMed]

91. Dong, C.; Gongora, R.; Sosulski, M.L.; Luo, F.; Sanchez, C.G. Regulation of transforming growth factor-beta1 (TGF- $\beta 1$ )-induced pro-fibrotic activities by circadian clock gene BMAL1. Respir. Res. 2016, 17, 4. [CrossRef]

92. Chen, W.-D.; Yeh, J.-K.; Peng, M.-T.; Shie, S.-S.; Lin, S.-L.; Yang, C.-H.; Chen, T.-H.; Hung, K.-C.; Wang, C.-C.; Hsieh, I.-C.; et al. Circadian CLOCK Mediates Activation of Transforming Growth Factor- $\beta$ Signaling and Renal Fibrosis through Cyclooxygenase 2. Am. J. Pathol. 2015, 185, 3152-3163. [CrossRef]

93. Kheir, T.B.; Futoma-Kazmierczak, E.; Skanderup, A.J.; Krogh, A.; Bardram, L.; Hother, C.; Grønbæk, K.; Federspiel, B.; Lund, A.H.; Friis-Hansen, L. miR-449 inhibits cell proliferation and is down-regulated in gastric cancer. Mol. Cancer 2011, 10, 29. [CrossRef]

94. Ma, S.; Zhao, Y.; Sun, J.; Mu, P.; Deng, Y. miR449a/SIRT1/PGC-1 $\alpha$ Is Necessary for Mitochondrial Biogenesis Induced by T-2 Toxin. Front. Pharmacol. 2018, 8. [CrossRef]

95. Xu, J.-Q.; Liu, P.; Si, M.-J.; Ding, X.-Y. MicroRNA-126 inhibits osteosarcoma cells proliferation by targeting Sirt1. Tumor Boil. 2013, 34, 3871-3877. [CrossRef]

96. Yamakuchi, M.; Lowenstein, C.J. MiR-34, SIRT1, and p53: The feedback loop. Cell Cycle 2009, 8, 712-715. [CrossRef]

97. Zhang, H.-S.; Chen, X.-Y.; Wu, T.-C.; Sang, W.-W.; Ruan, Z. MiR-34a is involved in Tat-induced HIV-1 long terminal repeat (LTR) transactivation through the SIRT1/NFKB pathway. FEBS Lett. 2012, 586, 4203-4207. [CrossRef]

98. Zhao, X.; Zhu, X.; Cheng, S.; Xie, Y.; Wang, Z.; Liu, Y.; Jiang, Z.; Xiao, J.; Guo, H. MiR-29a/b/c regulate human circadian gene hPER1 expression by targeting its 3'UTR. Acta Biochim. et Biophys. Sin. 2014, 46, 313-317. [CrossRef]

99. Ramírez, C.; Goedeke, L.; Rotllan, N.; Yoon, J.-H.; Cirera-Salinas, D.; Mattison, J.A.; Suárez, Y.; De Cabo, R.; Gorospe, M.; Fernández-Hernando, C. MicroRNA 33 Regulates Glucose Metabolism. Mol. Cell. Boil. 2013, 33, 2891-2902. [CrossRef]

100. Devanna, P.; Vernes, S.C. A direct molecular link between the autism candidate gene RORa and the schizophrenia candidate MIR137. Sci. Rep. 2014, 4, 3994. [CrossRef]

101. Chinnapaiyan, S.; Parira, T.; Dutta, R.K.; Agudelo, M.; Morris, A.; Nair, M.; Unwalla, H. HIV Infects Bronchial Epithelium and Suppresses Components of the Mucociliary Clearance Apparatus. PLoS ONE 2017, 12, e0169161. [CrossRef]

102. Unwalla, H.; Ivonnet, P.; Dennis, J.S.; Conner, G.E.; Salathe, M. Transforming Growth Factor- $\beta 1$ and Cigarette Smoke Inhibit the Ability of $\beta 2$-Agonists to Enhance Epithelial Permeability. Am. J. Respir. Cell Mol. Boil. 2015, 52, 65-74. [CrossRef]

103. Fernandes, J.; Acuña, S.M.; Aoki, J.I.; Floeter-Winter, L.M.; Muxel, S.M. Long Non-Coding RNAs in the Regulation of Gene Expression: Physiology and Disease. Noncoding RNA 2019, 5, 17. [CrossRef]

104. Coon, S.L.; Munson, P.J.; Cherukuri, P.F.; Sugden, D.; Rath, M.F.; Møller, M.; Clokie, S.; Fu, C.; Olanich, M.E.; Rangel, Z.; et al. Circadian changes in long noncoding RNAs in the pineal gland. Proc. Natl. Acad. Sci. USA 2012, 109, 13319-13324. [CrossRef]

105. Vollmers, C.; Schmitz, R.J.; Nathanson, J.; Yeo, G.; Ecker, J.R.; Panda, S. Circadian oscillations of protein-coding and regulatory RNAs in a highly dynamic mammalian liver epigenome. Cell Metab. 2012, 16, 833-845. [CrossRef] 
106. Palczewski, K.; Kevany, B.M.; Genoud, C.; Bai, X.; Palczewski, K. Photoreceptor phagocytosis is mediated by phosphoinositide signaling. FASEB J. 2013, 27, 4585-4595. [CrossRef]

107. Park, J.; Belden, W.J. Long non-coding RNAs have age-dependent diurnal expression that coincides with age-related changes in genome-wide facultative heterochromatin. BMC Genom. 2018, 19, 777. [CrossRef]

108. Park, J.; Zhu, Q.; Mirek, E.; Na, L.; Raduwan, H.; Anthony, T.G.; Belden, W.J. BMAL1 associates with chromosome ends to control rhythms in TERRA and telomeric heterochromatin. PLoS ONE 2019, 14, e0223803. [CrossRef]

109. Cui, M.; Zheng, M.; Sun, B.; Wang, Y.; Ye, L.; Zhang, X. A long noncoding RNA perturbs the circadian rhythm of hepatoma cells to facilitate hepatocarcinogenesis. Neoplasia 2015, 17, 79-88. [CrossRef]

110. Huang, Z.; Zhao, X.; Wu, X.; Xiang, L.; Yuan, Y.; Zhou, S.; Yu, W. LncRNA UCA1 facilitated cell growth and invasion through the miR-206/CLOCK axis in glioma. Cancer Cell Int. 2019, 19, 316-319. [CrossRef]

111. Chen, Y.; Huang, H.; Xu, C.; Yu, C.; Li, Y. Long Non-Coding RNA Profiling in a Non-Alcoholic Fatty Liver Disease Rodent Model: New Insight into Pathogenesis. Int. J. Mol. Sci. 2017, 18, 21. [CrossRef]

112. Wu, X.; Chen, L.; Zeb, F.; Huang, Y.; An, J.; Ren, J.; Yang, F.; Feng, Q. Regulation of circadian rhythms by NEAT1 mediated TMAO-induced endothelial proliferation: A protective role of asparagus extract. Exp. Cell Res. 2019, 382, 111451. [CrossRef] [PubMed]

113. Chen, L.; Wu, X.; Zeb, F.; Huang, Y.; An, J.; Jiang, P.; Chen, A.; Xu, C.; Feng, Q. Acrolein-induced apoptosis of smooth muscle cells through NEAT1-Bmal1/Clock pathway and a protection from asparagus extract. Environ. Pollut. 2020, 258, 113735. [CrossRef] [PubMed]

114. Bratkovič, T.; Rogelj, B. The many faces of small nucleolar RNAs. Biochim. et Biophys. Acta BBA Bioenerg. 2014, 1839, 438-443. [CrossRef]

115. Dupuis-Sandoval, F.; Poirier, M.; Scott, M.S. The emerging landscape of small nucleolar RNAs in cell biology. Wiley Interdiscip. Rev. RNA 2015, 6, 381-397. [CrossRef]

116. Jorjani, H.; Kehr, S.; Jedlinski, D.J.; Gumienny, R.; Hertel, J.; Stadler, P.F.; Zavolan, M.; Gruber, A. An updated human snoRNAome. Nucleic Acids Res. 2016, 44, 5068-5082. [CrossRef]

117. Massenet, S.; Bertrand, E.; Verheggen, C. Assembly and trafficking of box C/D and H/ACA snoRNPs. RNA Boil. 2016, 14, 680-692. [CrossRef]

118. Aitken, S.; Semple, C.A. The circadian dynamics of small nucleolar RNA in the mouse liver. J. R. Soc. Interface 2017, 14, 20170034. [CrossRef]

119. Powell, W.; Coulson, R.; Crary, F.K.; Wong, S.S.; Ach, R.A.; Tsang, P.; Yamada, N.A.; Yasui, D.H.; LaSalle, J. A Prader-Willi locus lncRNA cloud modulates diurnal genes and energy expenditure. Hum. Mol. Genet. 2013, 22, 4318-4328. [CrossRef]

120. Coulson, R.; Yasui, D.H.; Dunaway, K.; Laufer, B.; Ciernia, A.V.; Zhu, Y.; Mordaunt, C.; Totah, T.S.; LaSalle, J. Snord116-dependent diurnal rhythm of DNA methylation in mouse cortex. Nat. Commun. 2018, 9, 1616. [CrossRef]

121. Mei, Y.-P.; Liao, J.-P.; Shen, J.; Yu, L.; Liu, B.; Liu, L.; Li, R.-Y.; Ji, L.; Dorsey, S.G.; Jiang, Z.-R.; et al. Small nucleolar RNA 42 acts as an oncogene in lung tumorigenesis. Oncogene 2011, 31, 2794-2804. [CrossRef]

122. Mannoor, K.; Shen, J.; Liao, J.; Liu, Z.; Jiang, F. Small nucleolar RNA signatures of lung tumor-initiating cells. Mol. Cancer 2014, 13, 104. [CrossRef]

(C) 2020 by the authors. Licensee MDPI, Basel, Switzerland. This article is an open access article distributed under the terms and conditions of the Creative Commons Attribution (CC BY) license (http://creativecommons.org/licenses/by/4.0/). 